\title{
河西走廊沙漠人工植被区土壤种子库特征
}

\author{
占玉芳*,马 力, 滕玉风, 钱万建, 鲁延芳 \\ 张掖市林业科学研究院, 张掖 734000
}

摘要:土壤种子库作为地上植被更新的重要的种源储备库,在植被自然恢复和演替过程以及生态系统建设中起着重要作用。以 河西走廊不同区域沙漠人工植被为研究对象,研究了土壤种子库物种组成、时空分布和数量变化特征。结果表明: 河西走廊沙 漠人工林土壤种子库共出现 27 种植物, 分属 8 科 22 属, 以藜科植物最多, 生活型以草本植物种子比例最高, 占到 $90.6 \%-$ $95.06 \%$; 土壤种子库密度介于 19.29 粒 $/ \mathrm{m}^{2}-858.57$ 粒 $/ \mathrm{m}^{2}$ 之间, 从东到西呈水平地带性分布, 土壤种子库分布主要集中在 0 $2 \mathrm{~cm}$ 土层中, 不同样地土壤种子库密度均呈明显的垂直分布, 在 $0-10 \mathrm{~cm}$ 土层内, 随着土层深度增加, 种子库密度先减小后增 大; 土壤种子库多样性 (Simpson 指数) 在河西走廊东段沙漠人工植被区最高, 在 $0.671-0.812$ 之间, 河西走廊中段沙漠人工植被 区为 $0.417-0.809$ 之间,河西走廊西段沙漠人工植被区为 $0.256-0.707$ 之间, 从东到西呈下降趋势, Shannon-Wiener 指数、Margalett 丰富度指数、Peilow 均匀度指数也表现出相同的趋势, 说明由于生境的植被的异质性程度高, 使土壤种子库之间的差异性显著; 河 西走廊沙漠人工植被区的土壤种子库和地上植被的相似性系数均在 0.45 以下,为中等不相似水平,说明在组成上差异显著; 土壤 种子库以一年生、多年生草本为主, 也有少量灌木种子, 表明土壤种子库对灌木层更新和演替影响较小。研究证明了土壤种子库 中的大量种子,是地上植被自然恢复的重要物质基础,并对了解沙漠人工植被区植被自然恢复特点具有重要的贡献。

关键词 : 沙漠人工植被区;土壤种子库;物种多样性; 相似性

\section{Analysis of soil seed bank characteristics of artificial revegetated desert area in Hexi Corridor}

ZHAN Yufang * ,MA Li,TENG Yufeng, QIAN Wanjian,LU Yanfang

Zhangye Academy of Forestry, Zhangye 734000, China

\begin{abstract}
Soil seed bank, generally acknowledged as an important seed reserve for vegetation regeneration, plays an important role in the vegetation restoration and succession, as well as the ecosystems construction. The species composition, spatio-temporal distribution, and quantitative changes of re-vegetated desert areas in Hexi Corridor were investigated in this study. Results showed that there were 27 species of plants in the soil seed bank, belonging to 22 genera and 8 families, with the most common species in Chenopodiaceae. In terms of life-form, the seeds from herbs accounted for 90.6-95.06\%. The density of soil seed bank was between $19.29-858.57$ grains $/ \mathrm{m}^{2}$, showing a horizontal distribution pattern from east to west. The soil seed banks was mainly concentrated in the $0-2 \mathrm{~cm}$ soil layer in vertical direction. In the rang of $0-10 \mathrm{~cm}$ soil layer, there was an obvious vertical distribution pattern of seed density: with increase of soil depth, seed density first decreased then increased. Simpson Index in the soil seed bank was the highest in the re-vegetated areas of the east Hexi Corridor Desert $(0.671-0.812), 0.417-0.809$ of the middle Hexi Corridor Desert, and 0.256-0.707 of west Hexi Corridor Desert, with a downward trend from east to west. Shannon-Wiener Index, Margalett Richness Index and Peilow Evenness Index also showed the same trend. The large variation in species diversity indices among sites was most likely attributed by the high degree of inter-site vegetation heterogeneity. The similarity coefficients between soil seed bank and
\end{abstract}

基金项目:国家自然科学基金项目 (31560240)

收稿日期: 2020-01-17; 网络出版日期: 2021-10-11

* 通讯作者 Corresponding author.E-mail: zyf700104@ sina.com 
vegetation in the desert re-vegetated areas in Hexi Corridor were all below 0.45 , indicating a significant difference in species composition. The soil seed bank was dominated by annual and perennial herbs, with a few shrubs, which indicated that the soil seed bank played a minor role in the regeneration and succession of the shrub layer in the desert re-vegetated ecosystems. This study proved that a sufficient amount of seeds in soil seed bank is an important foundation for the natural restoration of vegetation in desert, and advanced our understanding of the natural vegetation restoration in the re-vegetated desert areas.

Key Words : artificial re-vegetated desert area; soil seed bank; biodiversity; similarity

土壤种子库 (Soil Seed Bank,SSB) 是指存在于土壤表面和土壤中的全部具有活力的种子的总和 ${ }^{[1]}$ 。土壤 种子库作为潜在的植物种群, 是植被潜在更新能力的重要组成部分, 在干旱荒漠区植被恢复与更新及生态系 统建设中发挥着重要的作用 ${ }^{[2]}$, 成为植物种群生态学和恢复生态学研究的热点问题之一。植物群落中地上 植被和土壤种子库的组成和格局的变化反映了植被演替的过程 ${ }^{[3]}$ 。土壤种子库的物种组成因不同植物群落 组成而不同, 掌握这些土壤种子库物种的动态, 不仅有助于理解在植物群落内部有重要限制作用的因子或过 程 ${ }^{[4-5]}$, 而且有利于科学地预测地上植被的演替及变化, 从而为植被的恢复与治理提供参考。

河西走廊是中国沙漠化最严重的地区之一 ${ }^{[6]}$,境内戈壁面积 $8.55 \times 10^{4} \mathrm{~km}^{2}$, 沙漠、戈壁和零星沙地面积达 $7.54 \times 10^{2} \mathrm{~km}^{2}$, 东、北、西三面被腾格里沙漠、巴丹吉林沙漠、库姆塔格三大沙漠包围 ${ }^{[7]}$ 。河西走廊干旱缺水,生 态环境极为脆弱 $\left.{ }^{8}\right]$, 加之人类活动对水资源的过度开发利用, 造成了天然绿洲退缩、地下水位下降、内陆河断 流、沙漠化扩大等严重的生态问题 ${ }^{[9]}$ 。开展沙漠化土地生态恢复成为该地区一项长期而艰巨的任务, 沙地人 工植被是有效遏制沙漠化发展的重要途径, 以梭梭为主的沙漠人工植物群落是河西走廊地区经济与社会可持 续发展的绿色屏障,对于该地区干旱荒漠生态系统的稳定、维持与发展具有重要的意义 ${ }^{[10]}$ 。对河西走廊以梭 梭为主的人工植被覆盖流沙产生的生态效应方面取得了一系列研究成果, 其退化与更新成为干旱区生态研究 的热点之一 ${ }^{[11]}$ 。长期以来, 人们强调地上人工固沙植被的建设而忽视了地下土壤种子库的研究与利用 ${ }^{[12]}$ 。 我国学者主要对民勤沙漠人工植被退化原因、土壤结皮、土壤养分、土壤水分动态开展大量研究 ${ }^{[13-17]}$ 。而关 于干旱沙区人工林土壤种子库相关研究更少, 仅见民勤绿洲边缘梭梭林衰败过程中土壤种子库动态及其与地 上植被的关系研究 ${ }^{[18]}$, 石羊河中游沙漠化逆转过程土壤种子库的动态变化研究 ${ }^{[12]}$ 。大量研究与实践证明, 只有具有丰富种子库的退化沙地生态系统才能在较短的时间内实现恢复,因此,开展沙地人工林种子库研究 对于沙漠化土地管理与生态恢复极为重要 ${ }^{[19]}$ 。本研究以河西走廊沙漠人工植被区为研究对象, 研究沙地人 工植被土壤种子库的组成、物种多样性特征以及与地上植被的关系, 进一步探讨该区土壤种子库对于植被恢 复的贡献,为干旱荒漠区生态系统生物多样性保护及植被恢复与重建提供一定的理论依据。

\section{1 研究区概况和研究方法}

1.1 研究区概况

研究区包括甘肃省民勤县 (位于河西走廊东北部,东、西、北三面被腾格里沙漠和巴丹吉林沙漠所包围)、 临泽县 (位于河西走廊中部、巴丹吉林沙漠南缘)、金塔县 (位于河西走廊西部北侧,巴丹吉林沙漠腹地), 地理 位置 $38^{\circ} 26^{\prime}-40^{\circ} 17^{\prime} \mathrm{N}, 102^{\circ} 54^{\prime}-99^{\circ} 23^{\prime} \mathrm{E}$, 属于典型大陆性干旱气候区, 自东而西年降水量渐少, 干燥度渐大, 年日照时数增加。年均温 $5.8-9.3^{\circ} \mathrm{C}$, 年降水量仅为 $40-400 \mathrm{~mm}$, 年降水量主要集中在 6-9 月, 所以大多数 植物种的生长和繁殖主要依赖于这个时期的大气降水, 年蒸发量却高达 1500-3000mm, 年日照时数 2550$3500 \mathrm{~h}$ 。土壤以灰棕漠土和风沙土为主, 其中灰棕漠土为地带性土壤。天然植被以白刺( Nitraria tangutorum)、泡泡刺 (Nitraria sphaerocarpa) 为主, 主要分布在丘间低地, 伴生有沙拐束 (Calligonum mongolicum)、雾冰黎 (Bassia dasyphylla)、白茎盐生草 (Halogeton arachnoideus)、碱蓬 ( Suaeda glauca)、沙蓬 (Agriophyllum squarrosum) 等。调查样地基本情况如表 1 所示。本研究主要以河西走廊自东向西(武威市民 勤县-张掖市临泽县-酒泉市金塔县) 的水热梯度为顺序, 研究沙漠人工梭梭林的土壤种子库特征。 


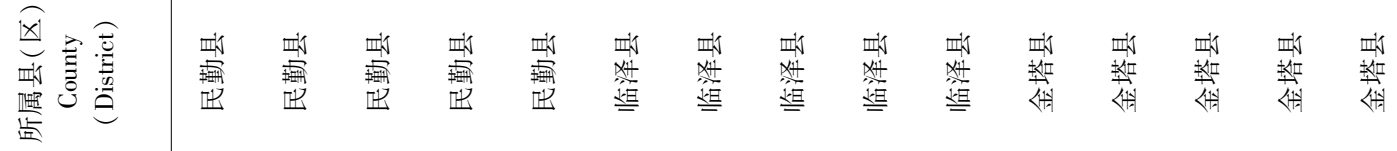

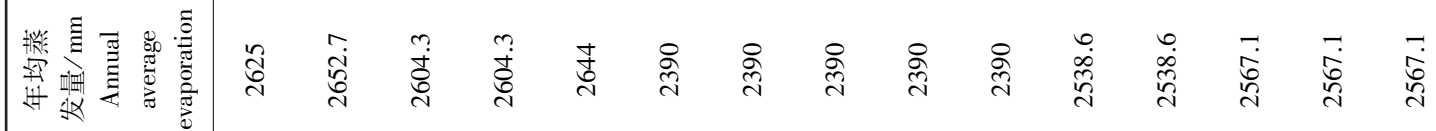

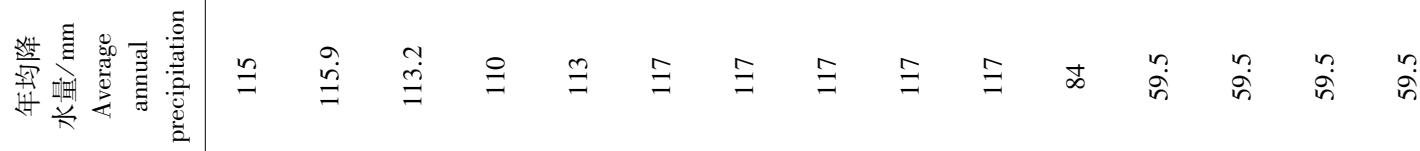

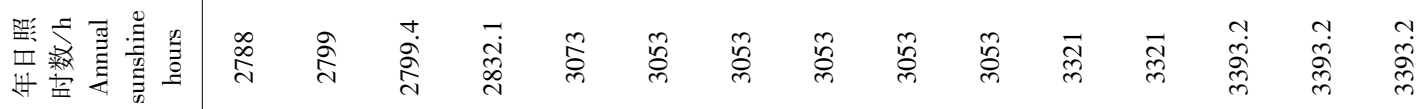

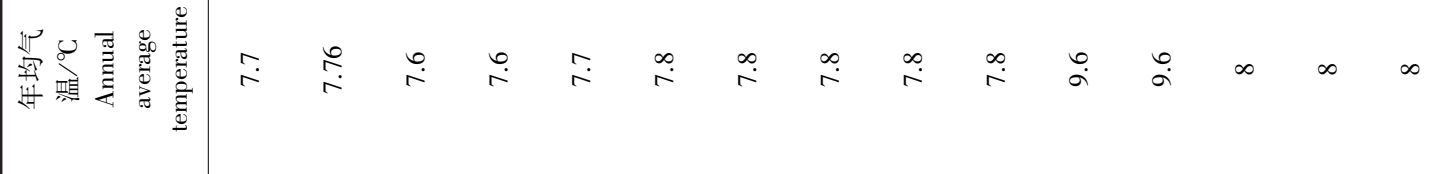

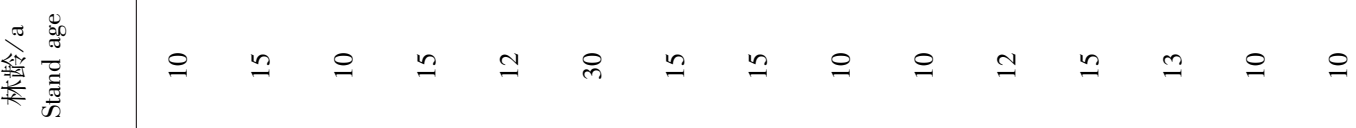

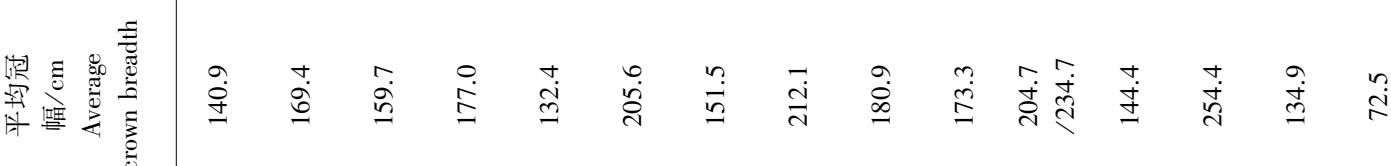

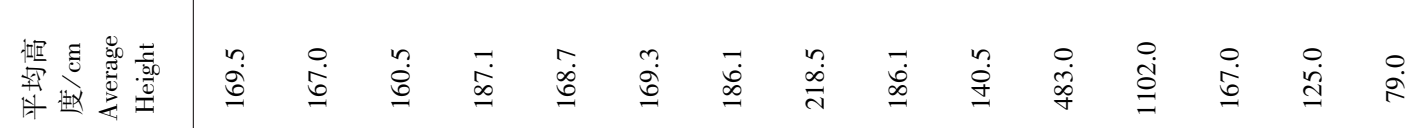

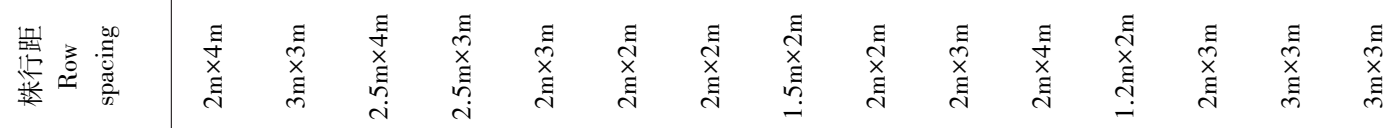

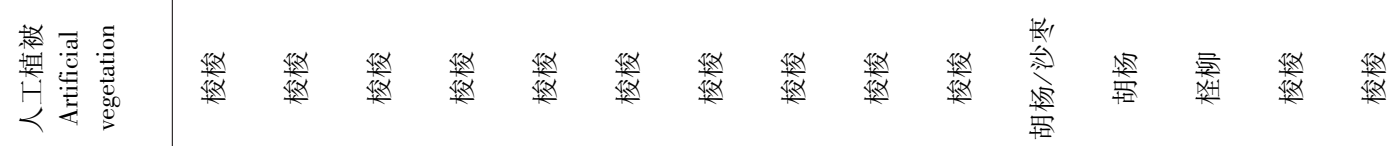

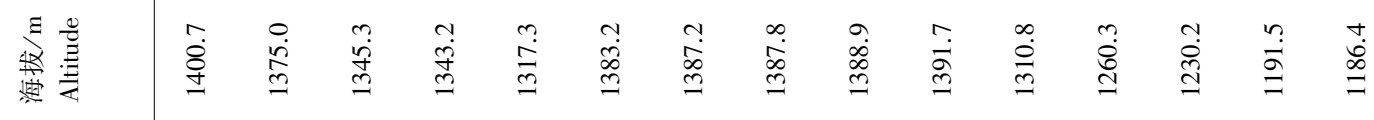

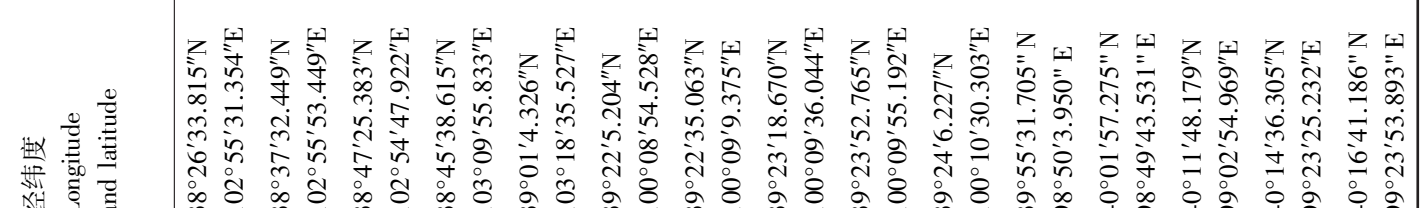

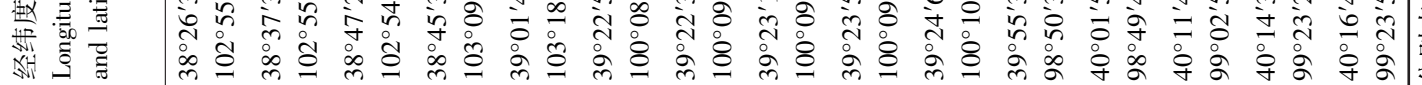

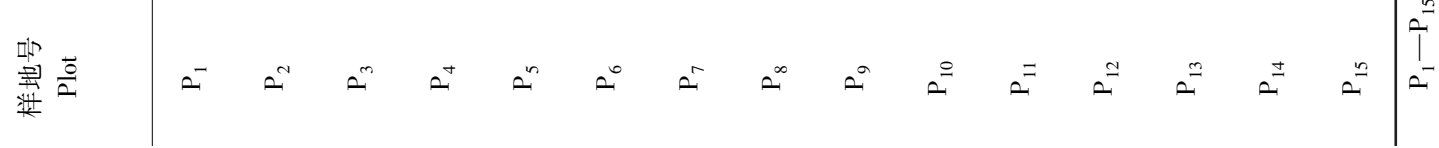




\section{2 研究方法}

\subsection{1 野外取样与调查}

样地设置: 通过查阅相关土壤和降水资料及实地考察, 确定河西走廊民勤县至金塔县自东向西,每个植被 区自北向南的经纬度梯度和水热梯度上的 15 个人工沙漠植被研究区 (表 1 )。

为全面研究人工沙漠植被区的土壤种子库结构特征, 在植物生长季节完全结束后进行土壤种子库采集取 样 ${ }^{[20]}$ 。2017 年和 2018 年的 4 月、10 月分别在河西走廊东段(民勤)、中部(临泽)、西段(金塔) 的沙漠人工植 被区设置 $50 \mathrm{~m} \times 50 \mathrm{~m}$ 样地 5 个,进行土壤种子库采样。沿样地 $(50 \mathrm{~m} \times 50 \mathrm{~m})$ 对角线等距 $(1 \mathrm{~m})$ “之”形布设样点, 每个样地布设 140 个取土样点, 共计 2100 个土壤种子库取土样点。采土样方的大小为 $10 \mathrm{~cm} \times 10 \mathrm{~cm}$, 深度为 $10 \mathrm{~cm}$, 分 $0-2 \mathrm{~cm} 、 2-5 \mathrm{~cm}$ 和 5- $10 \mathrm{~cm}$ 共 3 个土层采集土壤样品, 装人自封塑料袋, 带回室内。7-8 月进行地 上植被调查, 在每个样地 $(50 \mathrm{~m} \times 50 \mathrm{~m})$ 内设 $10 \mathrm{~m} \times 10 \mathrm{~m}$ 的灌木调查样方 5 个, 调查灌木的种类、数量、盖度、高 度、密度等信息,然后沿样地对角线等距 $(5 \mathrm{~m})$ 设 $1 \mathrm{~m} \times 1 \mathrm{~m}$ 草本调查样方 28 个, 调查草本植物的种类、数量、高 度、密度等。同时记录经纬度、海拔高度等样地信息。

\subsection{2 土壤种子库萌发试验}

5 月份土样风干后去除石块等杂物, 并将土样均匀平铺在底部垫有珍珠岩的育苗盘 $(45 \mathrm{~cm} \times 45 \mathrm{~cm} \times 10 \mathrm{~cm})$ 内, 种土厚 2-3cm, 置露天进行种子发芽和幼苗诊断, 发芽期间, 在育苗盘上面覆盖遮阳网, 不仅防止其它种 子被风吹人, 也有利于保持土样湿度。每天定时酒水 2 次, 保持样土湿润。出苗后, 根据其形态特征判别幼苗 种属, 一旦识别, 则视为有效种子, 记录其数, 并从育苗盘中拔除, 直到所有幼苗种属被识别为止, 萌发试验于 2018 年 5 月 10 日一 8 月 15 日进行。最后计算出 $\mathrm{lm}^{2}$ 内土壤种子库密度(即有效种子数)。

\subsection{3 数据处理}

(1)植物种生活型 ${ }^{[20-21]}$ : 分为乔木、灌木、半灌木、多年生草本和一年生草本植物 5 种类型, 计算植物种生 活型百分比。

(2)种子库的种子密度 ${ }^{[22]}$ : 采用单位面积 $(1 \mathrm{~m} \times 1 \mathrm{~m})$ 土壤内所含有的种子数量来表示。

$$
\text { 种子库密度 }\left(\text { 粒 } / \mathrm{m}^{2}\right)=\text { 种子数量 }(\text { 粒 }) / \text { 收集表面积 }\left(\mathrm{m}^{2}\right)
$$

采用 SPASS 19.0 进行方差分析 (one-way ANOVA), $\alpha=0.05$ :

(3)种子库物种多样性指数 ${ }^{[20,22-24]}$ : 采用 Shannon-Wiener 多样性指数、Simpson 多样性指数和 Margalett 丰 富度指数公式计算。公式如下:

Shannon-Wiener 多样性指数 $(H)$ :

$$
H=-\sum_{i=1}^{S}\left(P_{i} \ln P_{i}\right)
$$

Simpson 多样性指数 $(D)$ :

$$
D=1-\sum_{i=1}^{S}\left(P_{i}\right)^{2}
$$

Margalett 丰富度指数 $(R)$ :

$$
R=\frac{S-1}{\ln N}
$$

式中: $S$ 表示土壤种子库中所有物种总数; $P_{i}$ 表示第 $i$ 种植物的种子数占土壤种子库中总种子数比例; $N$ 表示 土壤种子库中所有物种的种子总数。

(4)种子库物种的均匀性指数 ${ }^{[20,22-24]}$ : 采用 Peilow 系数公式计算。公式为:

Peilow 均匀性系数 $(E)$ : 


$$
E=\frac{H}{\ln S}
$$

(5)土壤种子库、土壤种子库与地上植被相似性采用 Jaccard 相似性系数测度 ${ }^{[11]}$

Jaccard 相似性系数 $(S C)$ :

$$
S C=c /(a+b-c)
$$

当 Jaccard 相似性系数达到 $0.00-0.25$ 时为极不相似, $0.25-0.50$ 时为中等不相似, $0.50-0.75$ 时为中等 相似, $0.75-1.00$ 时为极相似。

(6)种子库物种百分比 ${ }^{[20]}$ : 土壤种子库中某一物种种子数占所有物种种子总数的百分比。

\section{2 结果与分析}

\section{1 种子库物种组成及生活型}

如表 2 所示, 本研究共调查种子库样地 15 个,共统计到植物种子 27 种, 分属 8 科 22 属, 其中, 藜科最多

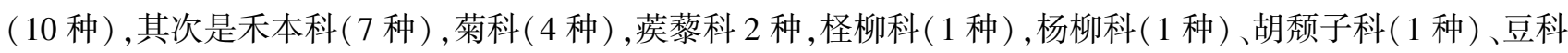
(1 种)。在河西走廊东段沙漠人工林土壤种子库中,共统计到植物种子 21 种,分属 6 科 21 属,其中,藜科最

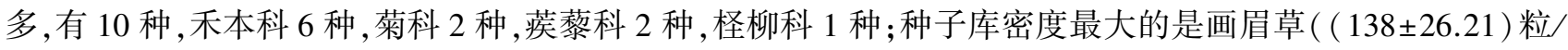
$\left.\mathrm{m}^{2}\right)$, 其次为刺沙蓬 $\left((41.43 \pm 5.01)\right.$ 粒 $\left./ \mathrm{m}^{2}\right)$ 、雾冰藜 $\left((32.86 \pm 4.85)\right.$ 粒 $\left./ \mathrm{m}^{2}\right)$ 。在河西走廊中段沙漠人工林土壤 种子库中共统计到植物种子 9 种, 其中,藜科 6 种, 禾本科 2 种, 教僽科 1 种; 种子库密度最大的是雾冰藜 $\left((121.00 \pm 10.14)\right.$ 粒 $\left./ \mathrm{m}^{2}\right)$, 其次为白茎盐生草 $\left((34.57 \pm 2.71)\right.$ 粒 $\left./ \mathrm{m}^{2}\right)$ 、梭梭 $\left((15.14 \pm 1.82)\right.$ 粒 $\left./ \mathrm{m}^{2}\right)$ 。在河西走 廊西段沙漠人工林土壤种子库中共统计到植物种子 19 种,其中,藜科 7 种,禾本科 5 种,菊科 4 种,杨柳科、胡 颓子科、柽柳科、豆科各 1 种; 种子库密度最大的是假苇拂子茅 $\left((127.86 \pm 22.54)\right.$ 粒 $\left./ \mathrm{m}^{2}\right)$, 其次是刺沙蓬 $\left((11.00 \pm 1.64)\right.$ 粒 $\left./ \mathrm{m}^{2}\right)$ 、胡杨 $\left((8.71 \pm 1.43)\right.$ 粒 $\left./ \mathrm{m}^{2}\right)$ 。

如图 1 所示, 在河西走廊沙漠人工林土壤种子库 0-2 cm 土层种子数所占种子库比例较大, 分别为 $65.01 \% 、 72.30 \% 、 48.51 \%, 2-5 \mathrm{~cm}$ 土层种子数所占种子库比例为 $15.18 \% 、 15.81 \% 、 32.63 \%, 5-10 \mathrm{~cm}$ 土层种子 数所占种子库比例最小, 为 $19.80 \% 、 11.89 \% 、 19.22 \%$ 。由此可见, 在河西走廊干旱区人工沙漠植被区 (年降水 量仅为 $40-400 \mathrm{~mm}), 0-2 \mathrm{~cm}$ 土层土壤种子库种子数所占比例最大, 也就是说土壤种子库种子主要集中在 $0-2 \mathrm{~cm}$ 土层, 占 $0-10 \mathrm{~cm}$ 土层种子库密度的 $48 \%$ 以上。
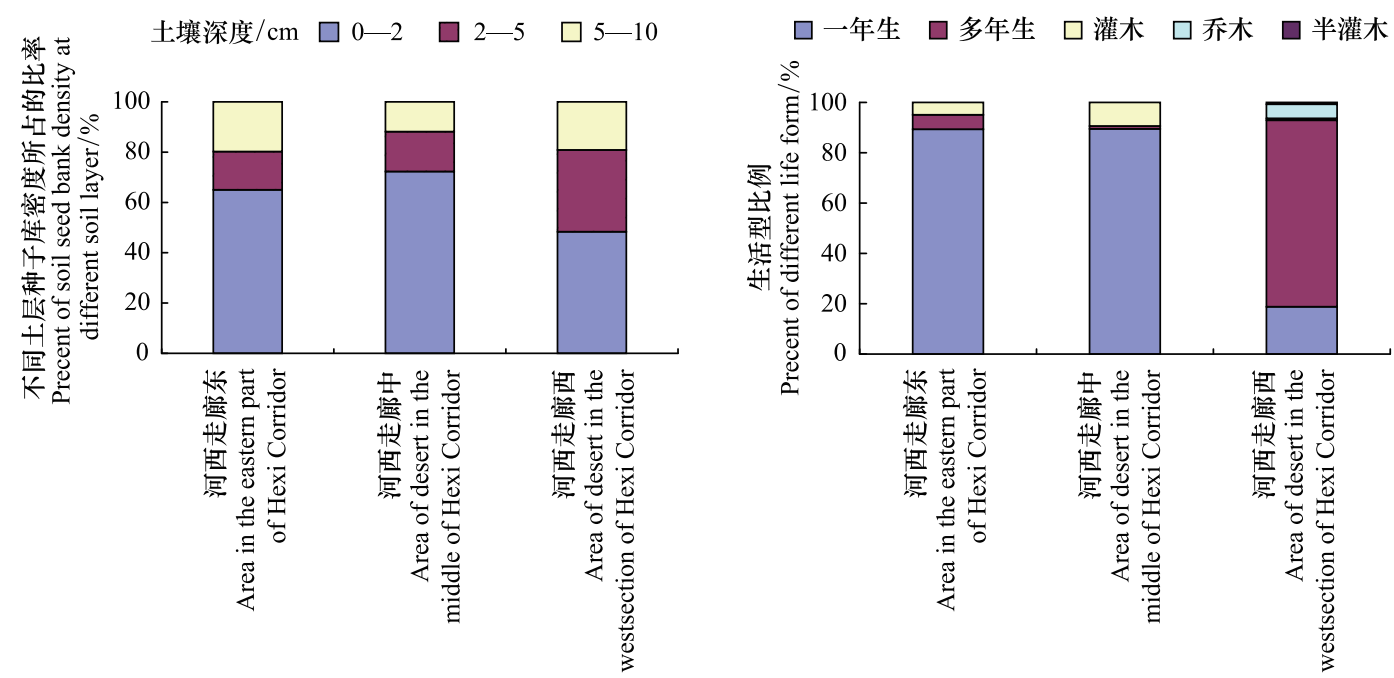

图 1 不同生活型植物和不同土层种子数量在各植被类型中所占比例

Fig.1 The percentage of different life form of soil seed banks and the percentage of seeds in different soil layers of different land cover types 


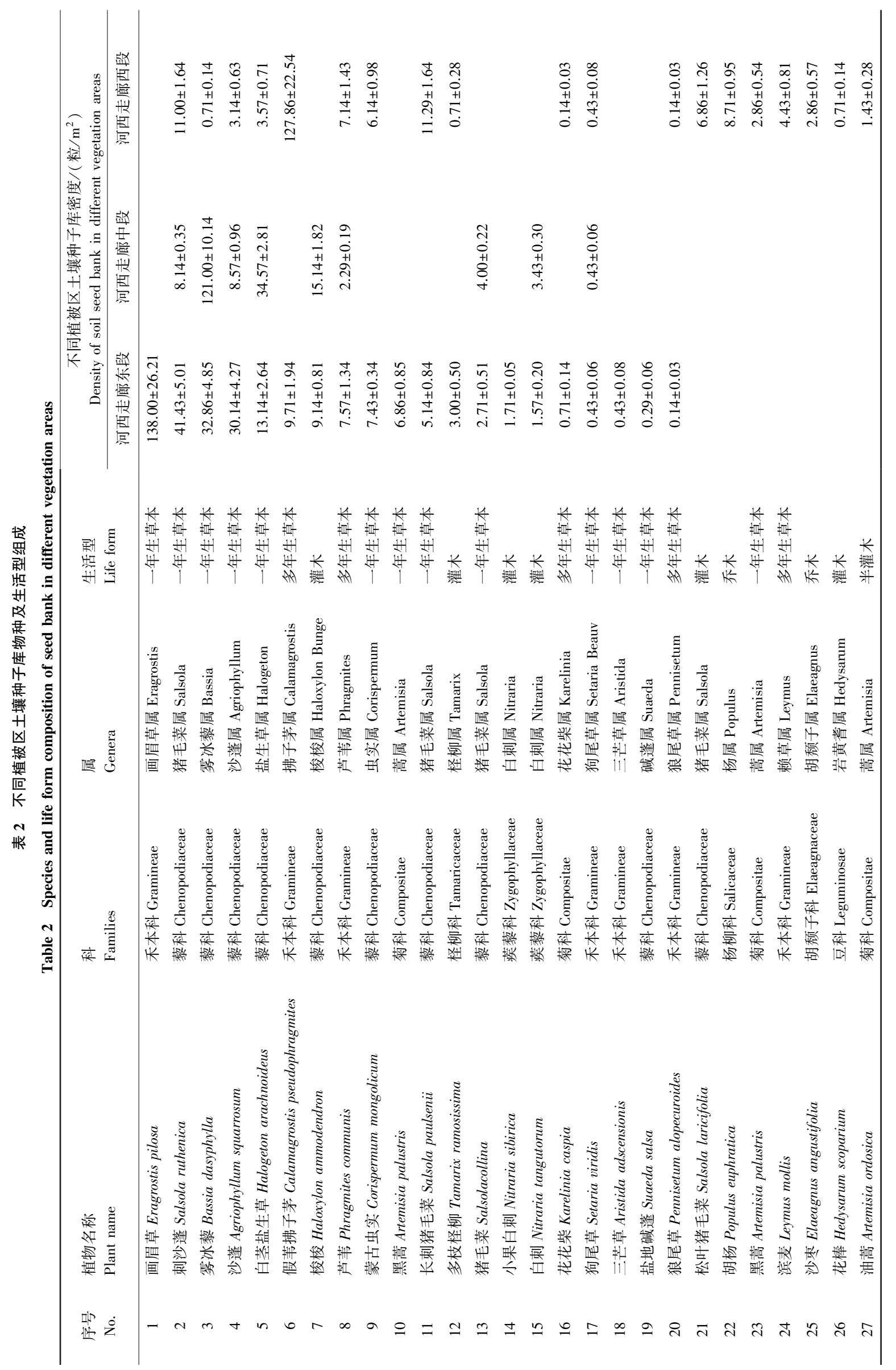


植物生活型是植物生长过程中对自然地理、气候变化的响应,具体反映在其生理、结构及形态上;在一定 程度上表征了区域环境气候特性、种群对空间利用方式及群落中不同种群间可能形成的竞争关系 ${ }^{[25-26]}$ 。本 研究中土壤种子库的物种生活型分析 (图 1) 可知,在降水量较大 ( $\geqslant 110 \mathrm{~mm}$ ) 的河西走廊东段、中部沙漠人工 梭梭林土壤种子库中, 以一年生草本植物种子最多, 分别达到了 $89.3 \% 、 89.44 \%$, 多年生草本植物种子分别为 $5.76 \% 、 1.16 \%$, 灌木种子分别为 $4.94 \% 、 9.4 \%$ 。在降水量小的河西走廊西段 (降水量仅为 $60 \mathrm{~mm}$ ) 人工沙漠植 被土壤种子库中, 多年生草本植物达到了 $74.24 \%$, 一年生草本植物占 $18.8 \%$ 、半灌木 $0.76 \%$ 、灌木 $0.76 \%$ 、乔木 $5.61 \%$ 。在河西走廊干旱沙漠区土壤种子库的物种生活型以草本植物占绝对优势, 而乔木和灌木生活型比例 很小。因此,在河西走廊沙漠人工林中草本层植物对荒漠植物群落结构、物种多样性维持方面具有重要的 意义。

2.2 土壤种子库密度分布特征

\subsection{1 不同样地土壤种子库密度}

图 2 表示了 15 个样地 $0-10 \mathrm{~cm}$ 土壤种子库密度, 从样地 $\mathrm{P}_{1}$ 到样地 $\mathrm{P}_{15}$, 种子库密度总体呈现指数性下降 趋势, 从河西走廊东段沙漠区、河西走廊中段沙漠区到 河西走廊西段沙漠区人工林, 降水量减小而热量增加, 这也说明种子库密度随着降水量的下降和热量的升高 呈现下降的趋势。总体而言, 位于河西走廊东段人工沙 漠植被区的样地 $\mathrm{P}_{5}$ 的种子库密度最大, 为 858.57 粒/ $\mathrm{m}^{2}$, 其次是样地 $\mathrm{P}_{4}$ 的种子库密度 522.86 粒 $/ \mathrm{m}^{2}$, 河西走 廊中段人工沙漠植被区的样地 $\mathrm{P}_{10}$ 的种子库密度 484.296 粒 $/ \mathrm{m}^{2}$, 土壤种子库密度最小的是河西走廊西段 人工沙漠植被区的样地 $\mathrm{P}_{12}$, 种子库密度仅为 19.29 粒/

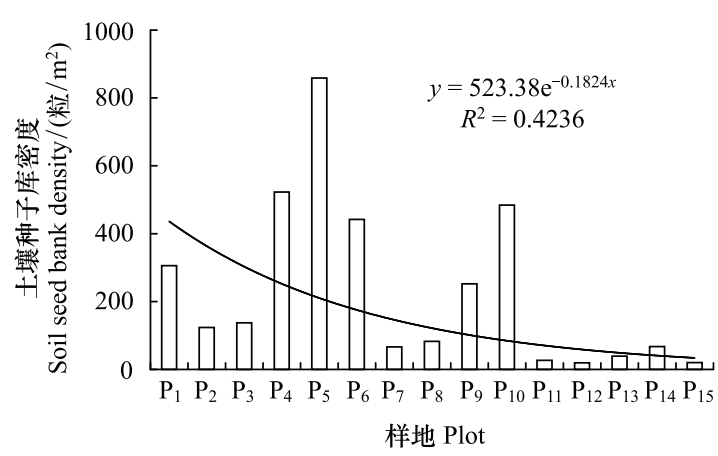

图 2 不同样地 $0-10 \mathrm{~cm}$ 土层的土壤种子库密度

Fig.2 Seed banks of $0-10 \mathrm{~cm}$ soil in different plots $\mathrm{P}_{1}-\mathrm{P}_{15}$ 分别表示第 1 至第 15 个样地 $\mathrm{m}^{2}$, 河西走廊西段人工沙漠植被区的样地 $\mathrm{P}_{15}$ 种子库密 度 20.00 粒 $/ \mathrm{m}^{2}$ 。河西走廊从东至西, 年均降水量减小, 年均蒸发量增大, 年均温度增高, 同时, 样地植被调查 结果也表明, 沙漠人工群落除梭梭以外主要以白刺、红砂等为主, 草本植物以雾冰泰、白茎盐生草等为主, 地表 植被稀疏, 而且地表主要以戈壁砾石或流沙为主,生境条件非常严酷,不利于一年生草本层片的形成和发育。

2.2.2 不同气温、降水量与土壤种子库密度

不同样地土壤种子库密度和气温、降水量之间的关系如图 3 所示。由图 3 可以看出, 随着气温的升高, 种 子库密度总体呈指数性下降趋势, 即土壤种子库密度与气温呈负相关关系。图 3 表示, 土壤种子库密度与降
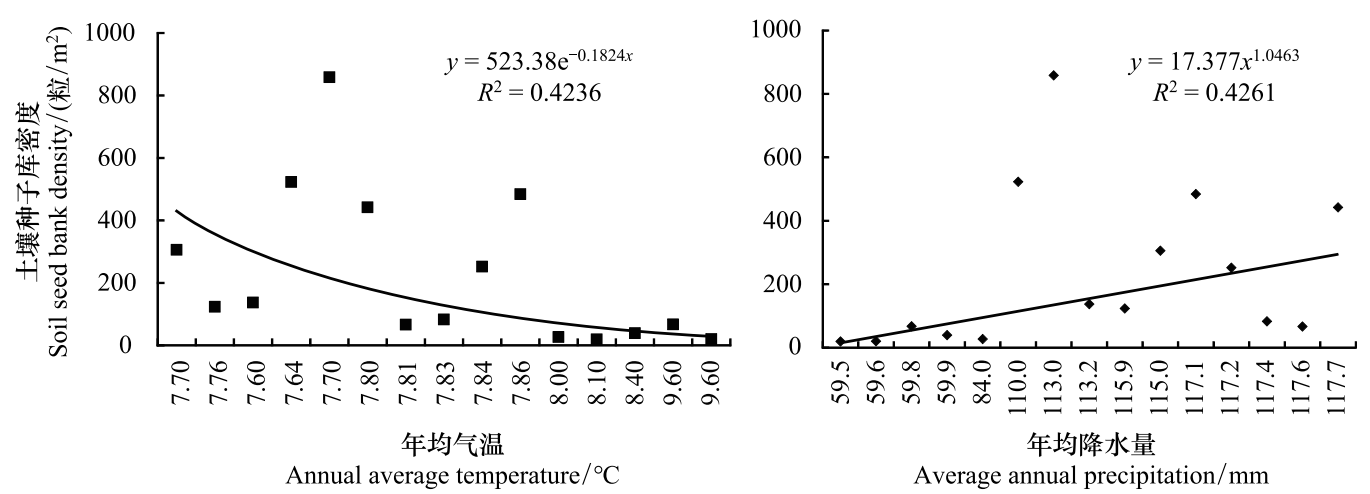

图 3 种子库密度和年均气温、降水量之间的关系

Fig.3 Relationship between seed bank density and annual average temperature and precipitation 
水量呈正相关关系, 说明随着降水量的增大, 土壤种子库密度总体呈增大趋势, 河西走廊从东到西, 沙漠人工 林植被的土壤种子库密度总体呈减小的趋势。由此可知, 河西走廊沙漠人工林土壤种子库的水平地带性分布 特征明显,影响土壤种子库密度差异的主要外界环境因素是由水、热分布的特性不同引起的。

\subsection{3 不同土壤深度土壤种子库密度}

土壤种子库具有明显的垂直分布特征, 对种子的萌发和留存、植被的恢复与重建产生一定的影响 ${ }^{[2]}$ 。通 过对不同样地不同土壤深度的种子库密度分析 (图 4), 土壤种子库种子主要分布在 $0-2 \mathrm{~cm}$ 的土层,其次分布 在 2-5 $\mathrm{cm}$ 的土层 $5-10 \mathrm{~cm}$ 的土层。0-2 $\mathrm{cm}$ 的土层平均种子密度 102.07 粒 $/ \mathrm{m}^{2}$, 占种子总数的 $51.64 \% ; 2-$ $5 \mathrm{~cm}$ 的土层平均种子密度 46.89 粒 $/ \mathrm{m}^{2}$, 占种子总数的 $24 \% ; 5-10 \mathrm{~cm}$ 的土层平均种子密度 48.67 粒 $/ \mathrm{m}^{2}$, 占种 子总数的 $24.36 \%$, 略高于 $2-5 \mathrm{~cm}$ 的土层。由此可见,随着土层深度的增加, 土壤种子库密度先减小后增大, 不同样地土壤种子库密度均呈明显的垂直分布, 河西走廊人工沙漠植被土壤种子库种子在土层中的分布依次 为土层 $0-2 \mathrm{~cm}>$ 土层 5-10cm > 土层 2- $5 \mathrm{~cm}$ 。土壤种子库中种子的垂直分布可能与不同植物群落土壤环境、 种子大小及物种繁殖策略的不同有关, 可能还与地上植被的覆盖及构建有关, 灌木类群落土壤种子库种子受 地上植被保护大多分布在土壤表层。李国旗等 ${ }^{[2]}$ 研究结果与本研究结果相一致。

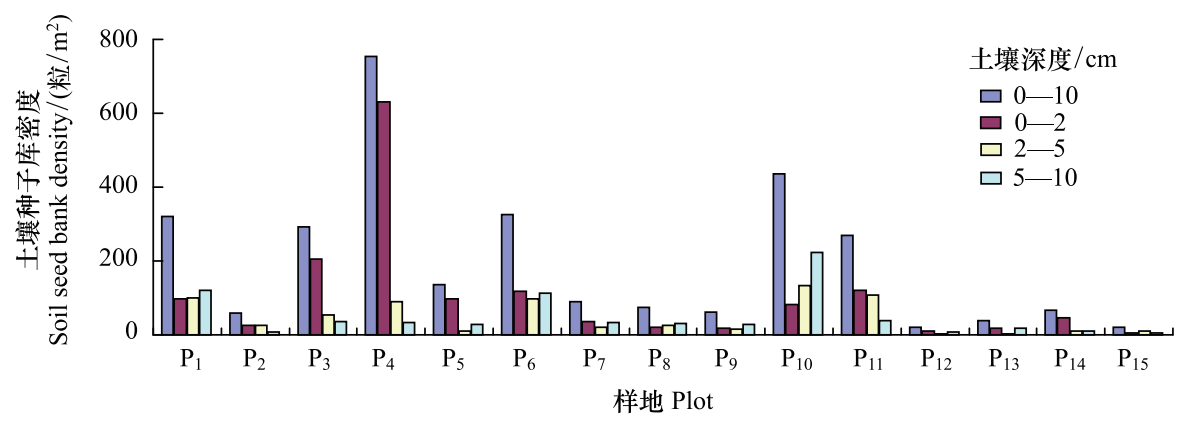

图 4 不同样地土壤种子库密度的垂直分布

Fig.4 Vertical distribution characteristics of soil seed bank density in different plot

图 5 可知,河西走廊东段沙漠人工林中, $0-2 \mathrm{~cm}$ 土层土壤种子库密度为 211.43 粒 $/ \mathrm{m}^{2}, 2-5 \mathrm{~cm}$ 土层土壤 种子库密度为 55.71 粒 $/ \mathrm{m}^{2}, 5-10 \mathrm{~cm}$ 土层土壤种子库密度为 45.29 粒 $/ \mathrm{m}^{2}$, 随土层深度增加, 土壤种子库密度 减小; 同样, 在河西走廊西段沙漠人工植被中, $0-2 \mathrm{~cm}$ 土层土壤种子库密度为 40.06 粒 $/ \mathrm{m}^{2}, 2-5 \mathrm{~cm}$ 土层土壤 种子库密度为 26.94 粒 $/ \mathrm{m}^{2}, 5-10 \mathrm{~cm}$ 土层土壤种子库密度为 15.87 粒 $/ \mathrm{m}^{2}$, 也是随土层深度增加而减小; 而在 河西走廊中部沙漠人工梭梭林中, $0-2 \mathrm{~cm}$ 土层土壤种子库密度为 54.71 粒 $/ \mathrm{m}^{2}, 2-5 \mathrm{~cm}$ 土层土壤种子库密度 为 58.00 粒 $/ \mathrm{m}^{2}, 5-10 \mathrm{~cm}$ 土层土壤种子库密度为 84.86 粒 $/ \mathrm{m}^{2}$, 土壤种子库密度随土层深度增加而增大。

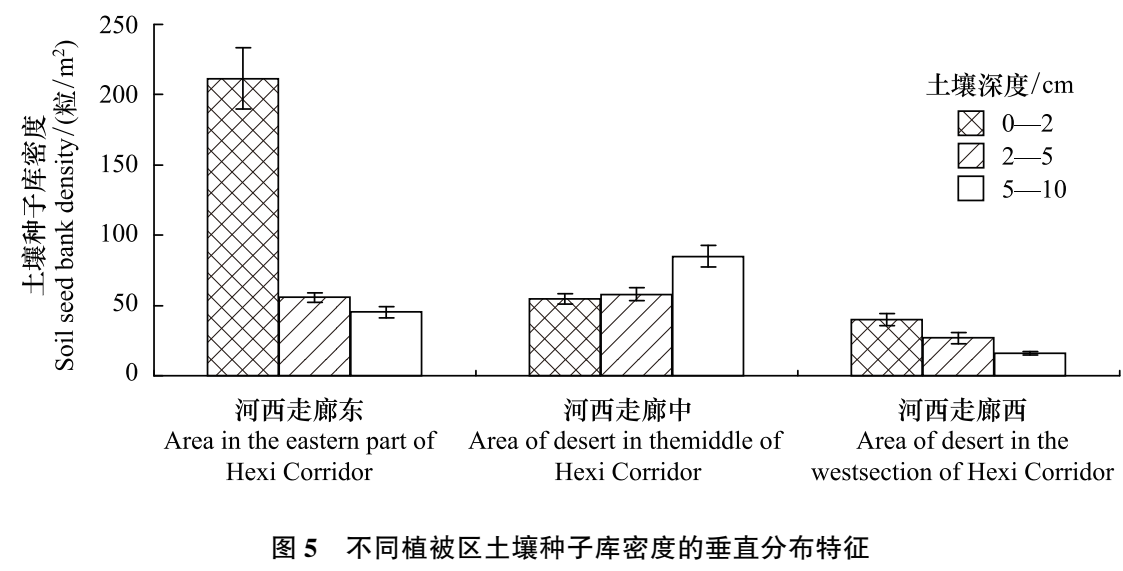

Fig.5 Vertical distribution characteristics of soil seed bank density in different vegetation areas 


\section{3 土壤种子库物种多样性变化}

由表 3 可知,河西走廊东段沙漠人工林中,土壤种子库的 Simpson 指数在 $0.671-0.812$ 之间, ShannonWiener 指数范围在 $0.636-1.990$ 之间,这两个指数均最高, 且具有较多物种数, 故具有较高的物种多样性; 河 西走廊中部沙漠梭梭林次之, Simpson 指数在 $0.417-0.809$ 之间, Shannon-Wiener 指数范围在 $0.874-1.810$ 之 间,而河西走廊西段沙漠人工林土壤种子库 Simpson 指数在 $0.256-0.707$ 之间, Shannon-Wiener 指数范围在 0.685-1.555 之间, 土壤种子库物种多样性较低。从河西走廊东段至西段, Simpson 指数、Shannon-Wiener 指 数大体呈下降趋势, 同时 Margalett 丰富度指数、Peilow 均匀度指数也表现出相同的趋势。因此,河西走廊从东 到西土壤种子库物种多样性指数呈现下降的趋势。

表 3 不同样地土壤种子库多样性和均匀度指数

Table 3 Diversity and evenness of soil seed banks of different plots

\begin{tabular}{ccccccc}
\hline $\begin{array}{c}\text { 样地 } \\
\text { plot }\end{array}$ & $\begin{array}{c}\text { 物种数/种 } \\
\text { Number of species }\end{array}$ & $\begin{array}{c}\text { 种子数/粒 } \\
\text { Seed number }\end{array}$ & $\begin{array}{c}\text { Shannon-Wiener } \\
\text { 多样性指数 } \\
\text { Shannon-Wiener } \\
\text { diversity index }\end{array}$ & $\begin{array}{c}\text { Margalett } \\
\text { 丰富度指数 } \\
\text { Margalett } \\
\text { richness ndex }\end{array}$ & $\begin{array}{c}\text { Simpson } \\
\text { 多样性指数 } \\
\text { Simpson } \\
\text { diversity index }\end{array}$ & $\begin{array}{c}\text { Pielou } \\
\text { 均匀度指数 } \\
\text { Pielou } \\
\text { evenness index }\end{array}$ \\
\hline $\mathrm{P}_{1}$ & 12 & 447 & 1.392 & 1.803 & 0.671 & 0.560 \\
$\mathrm{P}_{2}$ & 12 & 84 & 1.990 & 2.483 & 0.812 & 0.801 \\
$\mathrm{P}_{3}$ & 10 & 410 & 1.687 & 1.496 & 0.745 & 0.733 \\
$\mathrm{P}_{4}$ & 13 & 1054 & 0.636 & 1.724 & 0.225 & 0.248 \\
$\mathrm{P}_{5}$ & 8 & 192 & 1.565 & 1.331 & 0.724 & 0.753 \\
$\mathrm{P}_{6}$ & 7 & 457 & 0.874 & 0.980 & 0.417 & 0.449 \\
$\mathrm{P}_{7}$ & 7 & 124 & 1.223 & 1.245 & 0.568 & 0.629 \\
$\mathrm{P}_{8}$ & 7 & 105 & 1.189 & 1.289 & 0.558 & 0.611 \\
$\mathrm{P}_{9}$ & 9 & 85 & 1.810 & 1.801 & 0.809 & 0.824 \\
$\mathrm{P}_{10}$ & 9 & 612 & 1.365 & 1.247 & 0.633 & 0.621 \\
$\mathrm{P}_{11}$ & 9 & 376 & 1.555 & 1.036 & 0.707 & 0.668 \\
$\mathrm{P}_{12}$ & 6 & 27 & 1.417 & 1.517 & 0.705 & 0.791 \\
$\mathrm{P}_{13}$ & 5 & 55 & 0.957 & 0.998 & 0.548 & 0.595 \\
$\mathrm{P}_{14}$ & 5 & 94 & 0.685 & 1.045 & 0.256 & 0.253 \\
$\mathrm{P}_{15}$ & 3 & 28 & 0.706 & 0.600 & 0.426 & \\
\hline & & & & &
\end{tabular}

\section{4 土壤种子库相似性}

从表 4 中可以看出,河西走廊不同区域沙漠人工林的土壤种子库相似性差异较大。在河西走廊东段沙漠 人工林内 $\left(\mathrm{P}_{1}-\mathrm{P}_{5}\right)$, 相似性系数在 $0.20-0.69$ 之间, 相似性系数小于 0.7 , 没有达到中等相似水平, 说明不同 土壤种子库的物种组成存在较大差异。同样, 在河西走廊西段沙漠人工林内 $\left(\mathrm{P}_{11}-\mathrm{P}_{15}\right)$, 相似性系数在 $0.21-$ 0.57 之间, 相似性系数均小于 0.6 , 低于较低相似水平, 说明在河西走廊东段、西段沙漠人工林土壤种子库土壤 种子库之间相似性低于中等水平, 存在较大差异。在河西走廊中部沙漠人工林内 $\left(\mathrm{P}_{6}-\mathrm{P}_{10}\right)$, 相似性系数范围 在 0.56-0.89 之间, 属于中等相似水平; 因此, 在河西走廊沙漠人工林由于生境植被的异质性程度土壤种子库 之间的差异性显著。

2.5 土壤种子库与地上植被的关系

经调查 (图 6), 河西走廊人工沙漠植被区地上植被共有 40 种, 分属 13 科 37 属。图 6 可知, 以藜科植物

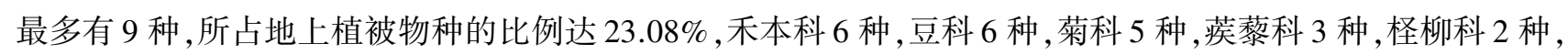
萻薇科 1 种,蓼科 1 种, 胡颓子科 2 种,杨柳科 2 种, 大戟科 1 种, 榆科 1 种, 白花丹科 1 种。河西走廊人工沙 漠植被区地上植被生活型以灌木为主(图 6), 所占比例 30\%,一年生草本占 $27.5 \%$,多年生草本占 $25 \%$ 。

在河西走廊人工林植被中, 土壤种子库与地上植被的共有的物种数较少, 所占地上植被物种的比例达 $50 \%$ 以上的有 $\mathrm{P}_{1} 、 \mathrm{P}_{2} 、 \mathrm{P}_{3} 、 \mathrm{P}_{4} 、 \mathrm{P}_{8} 、 \mathrm{P}_{9} 、 \mathrm{P}_{10}$, 其它样地均小于 $50 \%$; 所占土壤种子库物种的比例大于 $50 \%$ 的只有样 
地 $\mathrm{P}_{6} 、 \mathrm{P}_{7} 、 \mathrm{P}_{9}$, 其它均小于 $50 \%$ 。在河西走廊沙漠人工林中, 从东向西土壤种子库与地上植被的相似性系数呈 先增大后减小的趋势, 其中河西走廊中部的相似性系数在 $0.25-0.31$ 之间, 河西走廊东段的相似性系数在 0.18-0.30 之间,河西走廊西段的相似性系数在 0-0.24 之间, 属于较低相似水平 (图 7)。河西走廊沙漠人工 林土壤种子库与地上植被的物种组成方面差异显著, 地上植被除人工栽植的梭梭、红柳、胡杨以外, 还有红砂、 白刺、沙拐梞、河西菊等早生、中生灌木、半灌木, 土壤种子库中以一年生、多年生草本为主, 灌木种子很少, 由 此可见,土壤种子库对于沙区灌木层更新和演替的贡献较小 ${ }^{[20]}$, 由此可以更进一步认清干旱荒漠植被自然修 复特点。

表 4 不同样地土壤种子库物种相似性指数

Table 4 Similarities of seed banks of different plots

\begin{tabular}{|c|c|c|c|c|c|c|c|c|c|c|c|c|c|c|c|}
\hline 样地 plot & $\mathrm{P}_{1}$ & $\mathrm{P}_{2}$ & $\mathrm{P}_{3}$ & $\mathrm{P}_{4}$ & $\mathrm{P}_{5}$ & $\mathrm{P}_{6}$ & $\mathrm{P}_{7}$ & $\mathrm{P}_{8}$ & $\mathrm{P}_{9}$ & $\mathrm{P}_{10}$ & $\mathrm{P}_{11}$ & $\mathrm{P}_{12}$ & $P_{13}$ & $\mathrm{P}_{14}$ & $\mathrm{P}_{15}$ \\
\hline \multicolumn{16}{|l|}{$\mathrm{P}_{1}$} \\
\hline $\mathrm{P}_{2}$ & 0.41 & & & & & & & & & & & & & & \\
\hline $\mathrm{P}_{3}$ & 0.57 & 0.69 & & & & & & & & & & & & & \\
\hline $\mathrm{P}_{4}$ & 0.56 & 0.39 & 0.35 & & & & & & & & & & & & \\
\hline $\mathrm{P}_{5}$ & 0.33 & 0.25 & 0.20 & 0.31 & & & & & & & & & & & \\
\hline $\mathrm{P}_{6}$ & 0.36 & 0.27 & 0.31 & 0.43 & 0.50 & & & & & & & & & & \\
\hline $\mathrm{P}_{7}$ & 0.36 & 0.36 & 0.31 & 0.82 & 0.36 & 0.75 & & & & & & & & & \\
\hline $\mathrm{P}_{8}$ & 0.27 & 0.27 & 0.31 & 0.33 & 0.50 & 0.56 & 0.56 & & & & & & & & \\
\hline $\mathrm{P}_{9}$ & 0.33 & 0.33 & 0.29 & 0.50 & 0.45 & 0.88 & 0.88 & 0.67 & & & & & & & \\
\hline $\mathrm{P}_{10}$ & 0.31 & 0.40 & 0.36 & 0.38 & 0.42 & 0.78 & 0.78 & 0.78 & 0.89 & & & & & & \\
\hline $\mathrm{P}_{11}$ & 0.50 & 0.40 & 0.58 & 0.47 & 0.42 & 0.33 & 0.33 & 0.33 & 0.31 & 0.29 & & & & & \\
\hline $\mathrm{P}_{12}$ & 0.20 & 0.20 & 0.33 & 0.19 & 0.08 & 0.00 & 0.00 & 0.00 & 0.00 & 0.00 & 0.43 & & & & \\
\hline$P_{13}$ & 0.21 & 0.21 & 0.25 & 0.20 & 0.18 & 0.09 & 0.09 & 0.00 & 0.08 & 0.08 & 0.27 & 0.57 & & & \\
\hline $\mathrm{P}_{14}$ & 0.25 & 0.18 & 0.20 & 0.17 & 0.07 & 0.00 & 0.00 & 0.07 & 0.00 & 0.06 & 0.29 & 0.40 & 0.30 & & \\
\hline $\mathrm{P}_{15}$ & 0.07 & 0.07 & 0.08 & 0.07 & 0.10 & 0.00 & 0.00 & 0.00 & 0.00 & 0.00 & 0.21 & 0.50 & 0.33 & 0.38 & \\
\hline
\end{tabular}
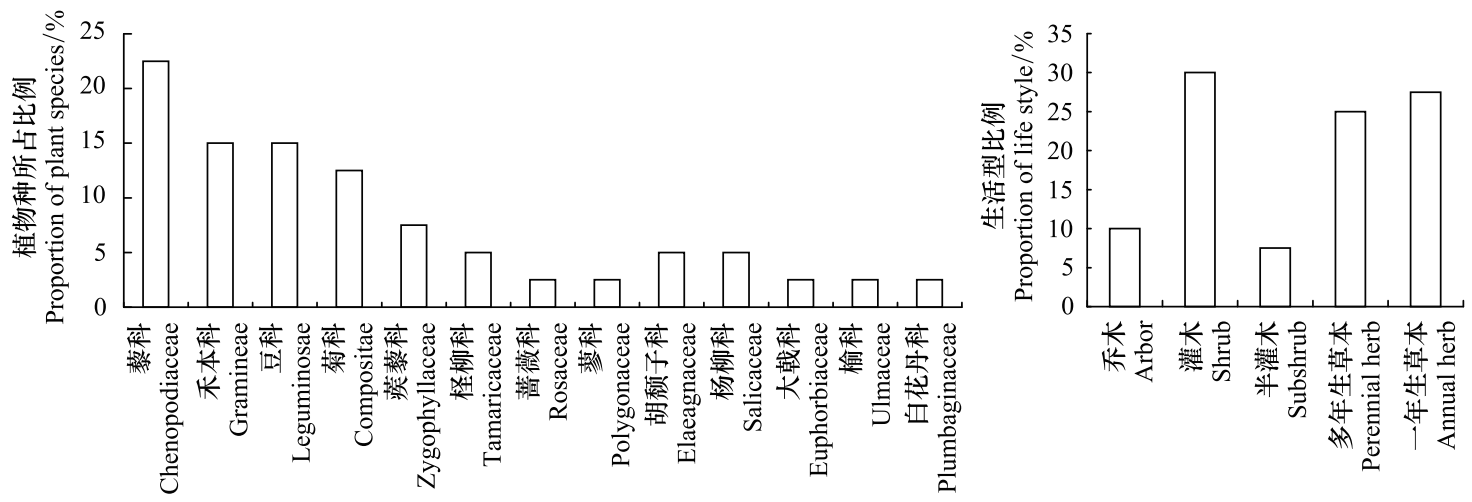

图 6 河西走廊沙漠人工植被区地上植物

Fig.6 Aboveground plants in desert artificial vegetation area of Hexi Corridor

\section{3 讨论}

土壤种子库作为植物对胁迫环境适应机制和植被恢复演替研究的关键内容 ${ }^{[27-28]}$, 已成为生物地理学和 种子生态学的重要研究领域 ${ }^{[28-29]}$ 。由于干旱荒漠生态系统生境异质性强, 土壤种子库在水平和垂直方向上 


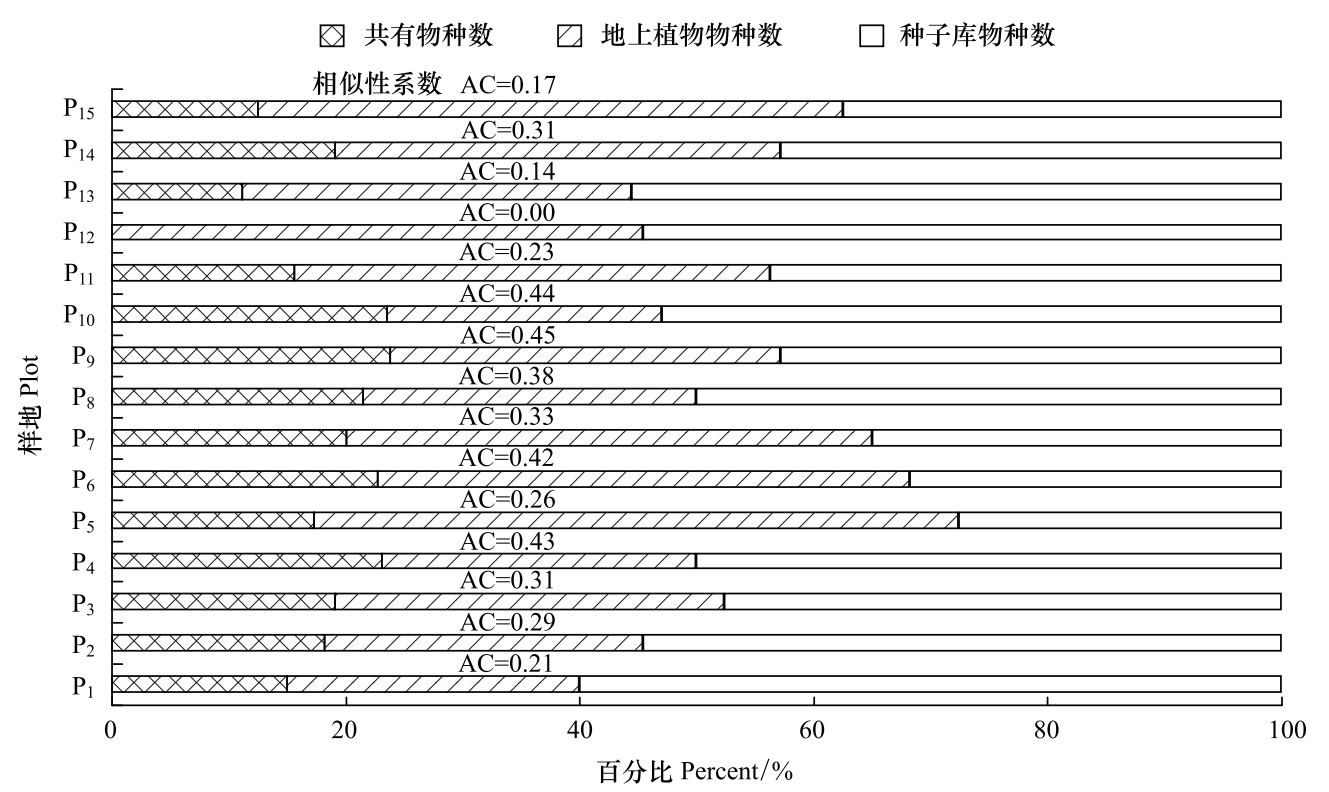

图 7 河西走廊沙漠人工林土壤种子库与现有地上植被的关系

Fig.7 Relationship between the standing vegetation and soil seed bank in different plots

的分布具有较大的变异性。沙漠地区由于强烈的风蚀和沙埋改变地表土层深度,从而使种子库密度和组成随 土层深度而变化 ${ }^{[19]}$ 。因此本研究中分 $0-2 、 2-5 、 5-10 \mathrm{~cm}$ 不同层次采集土壤样品研究沙漠人工植被区的土 壤种子库,以减少取样的随机误差, 提高取样的精确性 ${ }^{[29-30]}$ 。

在我国干旱荒漠区,尤其在沙漠生态系统人工植被区, 土壤种子库在植物多样性保护和植被恢复与重建 起着十分关键的作用 ${ }^{[30-31]}$, 与森林、草地相比数量与种类组成比较简单。通过对河西走廊沙漠人工林土壤种 子库组成分析研究, 共统计到植物种子 27 种, 分属 8 科 22 属。在河西走廊沙漠人工林中, 统计到的植物种子 生活型由草本、灌木、半灌木、乔木组成, 其中一年生草本植物占总体的 $65.85 \%$, 多年生草本占总体的 27. $05 \%$, 灌木占 $5.03 \%$, 乔木占 $5.61 \%$, 半灌木占 $0.76 \%$ 。种子库中以一年生草本植物占绝对优势, 这与赵文智对 科尔沁沙地土壤种子库 ${ }^{[31]}$ 、刘晓霞对浑善达克沙地土壤种子库研究 ${ }^{[32]}$ 结果类似。这可能是由于干旱沙区降 雨量极少,并且几乎集中分布在 7-9 月份期间,只有雾冰藜、白茎盐生草、画眉草等一年生短命沙旱生植物才 能完成生命周期, 并产生大量种子。与腾格里沙漠南缘和科尔沁沙漠地区相比 ${ }^{[33-34]}$, 河西走廊沙漠人工植被 土壤种子库组成相对简单, 与典型干旱、极端干旱区的研究结论相似 ${ }^{\left[{ }^{[3-36]}\right.}$, 这与沙区人工植被区群落组成相 对单一和种子植物相对较少密切相关,但根本上还是干旱少雨、风蚀沙埋生境影响的结果。

土壤种子库是植被自然恢复的物质基础, 其数量特征是判断地上植被恢复能力的依据 ${ }^{[37]}$ 。不同生态系 统的土壤种子库的数量存在显著差异, 森林、草地生态系统土壤种子库密度大, 组成较复杂, 而荒漠生态系统 土壤种子库组成简单, 数量较少。在本研究中, 土壤种子库密度介于 $19.29-858.57$ 粒 $/ \mathrm{m}^{2}$ 之间, 甚至低于干 旱、极端干旱地区沙漠土壤种子库数量 ${ }^{[38-40]}$, 这与前人研究其他沙漠区土壤种子库密度研究结果相一致。

河西走廊沙漠人工植被区土壤种子库的水平地带性分布与温度、降水量之间呈显著相关性,水平地带性 分布特征明显, 说明水平方向的水、热梯度是影响河西走廊沙漠人工植被区土壤种子库密度的主要外界因 素 ${ }^{[30]}$ 。有研究认为, 降水量极少是荒漠区土壤种子库密度低的原因之一 ${ }^{[20,41]}$, 而沙漠植被区种子库密度低 的原因与其地上植被稀少有关, 这和本节的研究结论一致。随着降水量的降低, 沙漠人工林土壤种子库密度 减小, 尤其是一年生草本植物土壤种子库密度也明显减小, 如在位于金塔的样地 $\mathrm{P}_{15}$ 中, 土壤种子库密度仅为 20.0 粒 $/ \mathrm{m}^{2}$, 地上植被除了栽植的梭梭外, 几乎没有其它植物。所以在干旱环境不利于种子库的存在。

本研究结果表明, 河西走廊沙漠人工植被区土壤种子库中植物种子密度的垂直分布规律土层 $0-2 \mathrm{~cm}>$ 土 层 5- $10 \mathrm{~cm}>$ 土层 2-5cm, 随着土壤深度的增加而先减小后增大, 这与塔克拉玛干沙漠北缘 ${ }^{[42]}$ 、古尔班通古 
特沙漠地区 ${ }^{[43]}$ 的研究结果不一致。本研究中, 土壤种子库主要集中在 $0-2 \mathrm{~cm}$ 土层中, 这与沙漠中绝大部分 种子存在于土壤表层的研究结果一致 ${ }^{[11,44-45]}, 5-10 \mathrm{~cm}$ 也有较多种子存在, 这主要是由于植被区流沙质地由 于风沙吹蚀、沙埋增加了种子进人土壤深层的机会。

土壤种子库与地上植被的关系研究是土壤种子库研究的热点内容之一 ${ }^{[10]}$ 。前期研究表明, 森林生态系 统中土壤种子库与地上植被相似性较低 (平均值 $31 \%$ ), 草地生态系统的相似性较高 (平均值 54\%), 湿地生态 系统的相似性为中等(平均值 $47 \%$ )。而本研究中发现河西走廊沙漠人工植被区土壤种子库与地上植被相似 性较低, 大多数样地低于 0.50 , 属于较低相似水平。同时, 土壤种子库与地上植被相似性从东至西呈先增大后 减小的趋势,这可能与降水少、地下水位下降而降低了土壤种子库与地上植被的相似性有关。

\section{4 结论}

河西走廊沙漠人工植被区, 土壤种子库共统计到 27 种植物种子, 分属 8 科 22 属。以僽科植物最多,生活 型包括一年生草本、多年生草本、半灌木、灌木、乔木植物, 其中, 一年生草本植物种子的比例达到了 $89 \%$ 以 上, 是沙漠人工林土壤种子库的主体。土壤种子库密度介于 $19.29-858.57$ 粒 $/ \mathrm{m}^{2}$ 之间, 属于干旱、极端干旱 沙漠区土壤种子库密度。河西走廊沙漠人工植被区土壤种子库密度呈水平地带性分布特征, 主要受水、热梯 度的影响, 从东向西, 随着温度升高、降水量降低, 土壤种子库密度呈下降趋势。土壤种子库中植物种子主要 集中在 0- $2 \mathrm{~cm}$ 的土层中, $5-10 \mathrm{~cm}$ 的土层中也有相当一部分种子。土壤种子库密度均呈明显的垂直分布, 土 壤种子库种子在土层中的分布依次为土层 0-2 $\mathrm{cm}>$ 土层 5-10cm>土层 2-5 cm, 随着土层增加, 土壤种子库 密度总体呈下降趋势。土壤种子库多样性低, 从东向西总体呈下降趋势。河西走廊不同区域沙漠人工植被区 的土壤种子库由于生境植被的异质性使土壤种子库之间的相似性差异较大,在河西走廊东段沙漠人工植被区 相似性系数在 $0.20-0.69$ 之间, 河西走廊中部沙漠人工植被区相似性系数范围在 $0.56-0.89$ 之间, 而河西走 廊西段沙漠人工植被区相似性系数在 $0.21-0.57$ 之间。河西走廊沙漠人工植被区土壤种子库和地上植被组 成差异显著, 地上植被以旱生、中生灌木、半灌木为主, 而土壤种子库中以一年生、多年生草本为主, 说明土壤 种子库对于灌木层更新和演替的贡献很小。

\section{参考文献( References) :}

[ 1 ] Roberts H A. Seed banks in soils. Advances in Applied Biology, 1981, 6: 1-55.

[ 2 ] 李国旗, 郡文山, 赵盼盼, 靳长青, 陈彦云. 荒漠草原区 4 种植物群落土壤种子库特征及其土壤理化性质. 生态学报, 2019, 39(17): 6282-6292.

[ 3 ] 杨否, 王彦荣, 余进德. 干旱荒漠区土壤种子库研究进展. 草业学报, 2010, 19(2): 227-234.

[ 4 ] 李国旗, 郡文山, 赵盼盼, 靳长青. 封育对荒漠草原两种植物群落土壤种子库的影响. 草业学报, 2018, 27(6): 52-61.

[ 5 ] 张玲, 方精云. 太白山土壤种子库储量与物种多样性的垂直格局. 地理学报, 2004, 59(6): 880-888.

[ 6 ] 李晓婧, 白艳萍, 李萌, 马金辉. 河西走廊水资源变化与生态环境时空关联分析. 水土保持通报, 2019, 39(2) : 275-280, 287-287.

[ 7 ] 常兆丰. 甘肃河西 60 年防沙治沙的问题及出路. 干旱区资源与环境, 2019, 33(9)：152-159.

[ 8 ] 梅锦山, 张建永, 李扬, 王忠静. 河西走廊生态保护战略研究. 水资源保护, 2014, 30(5): 21-25.

[ 9 ] 李志刚. 河西走廊人居环境保护与发展模式研究. 北京: 中国建筑工业出版社, 2010.

[10］吕朝燕, 张希明, 高智席, 熊佰炼, 韩畅, 王加真. 准噶尔盆地梭梭土壤种子库基本特征. 植物研究, 2017, 37(1): 109-117.

[11] 马全林, 卢琦, 魏林源, 靳虎甲. 干旱荒漠白刺灌丛植被演替过程土壤种子库变化特征. 生态学报, 2015, 35(7): 2285-2294.

[12] 马全林, 张德魁, 刘有军, 靳虎甲, 陈芳. 石羊河中游沙漠化逆转过程土壤种子库的动态变化. 生态学报, 2011, 31(4) : 989-997.

[13] 陈芳, 纪永福, 张锦春, 丁峰, 刘有军, 刘虎俊, 王芳琳. 民勤梭梭人工林天然更新的生态条件. 生态学杂志, 2010, 29(9): 1691- 1695.

[14] 王继和，马全林. 民勤绿洲人工梭梭林退化现状、特征与恢复对策. 西北植物学报，2003，23(12): 2107-2112.

[15] 张锦春, 纪永福, 王芳林, 陈芳, 王基金, 王功时, 曹虎. 民勤退化人工梭梭种群雨养恢复试验研究. 西北林学院学报, 2010, 25(1)： $77-81$.

[16] 吴利禄, 高翔, 褚建民, 王鹤松, 袁祺, 段晓峰, 郭树江. 民勤绿洲-荒漠过渡带梭梭人工林净碳交换及其影响因子. 应用生态学报, $2019,30(10): 3336-3346$. 
[17] 丁爱强, 徐先英, 刘江, 崔文天, 张荣娟, 赵鹏, 付贵全. 民勤绿洲自然稀疏人工梭梭林土壤水分动态. 水土保持研究, 2018, 25( 5) : 192-198.

[18］何芳兰, 郭春秀, 马俊梅, 吴吴, 金红喜. 民勤绿洲边缘梭梭林衰败过程中土壤种子库动态及其与地上植被的关系. 生态学报, 2018, 38 (13) : 4657-4667.

[19］唐毅, 刘志民. 沙丘生态系统种子库研究现状、趋势与挑战. 植物生态学报, 2012, 36( 8) : 891-898.

[20］何明珠. 阿拉善高原荒漠植被组成分布特征及其环境解释IV.土壤种子库特征研究. 中国沙漠, 2010, 30(2) : 287-295.

[21] 吴征镒. 中国植被. 北京: 科学出版社,1980.

[22] 占玉芳, 马力, 甄伟玲, 滕玉风, 钱万建, 穆刚. 河西走廊中部沙漠人工梭梭林土壤种子库特征.林业科技通讯, 2019, (9):54-58.

[23] 马坚, Beatrice Vonlanthen, Helge Bruelheide, 杨远昭, 李利, 王纯利, 张希明. 策勒沙漠-绿洲过渡带土壤种子库的基本特征. 新疆农业大 学学报, 2007, 30(3) :53-59.

[24] 任继周. 草业科学研究方法. 北京: 中国农业出版社, 1998.

[25] 杨朗生, 刘兴良, 刘世荣, 潘红丽, 冯秋红, 李迈和. 卧龙巴郎山川滇高山栋群落植物生活型海拔梯度特征. 生态学报, 2017, 37(21)： 7170-7180.

[26] 奘永军, 陈秀莉, 赵艳玲. 包头地区野生种子植物区系组成及特征研究. 西北植物学报, 2018, 38(2): 363-369.

[27] Qiu J, Bai Y G, Fu Y B, Wilmshurst J F. Spatial variation in temperature thresholds during seed germination of remnant Festuca hallii populations across the Canadian prairie. Environmental and Experimental Botany, 2010, 67(3): 479-486.

[28] 马红媛, 梁正伟, 吕丙盛, 杨吴谕, 王淑红. 松嫩碱化草甸土壤种子库格局、动态研究进展. 生态学报, 2012, 32(13): 4261-4269.

[29] Fenner M. Seeds: The Ecology of Regeneration in Plant Communities. 2nd ed. Wallingford: CABI Press, 2000.

[30] 陈孟晨, 张景光, 冯丽, 滕嘉玲. 沙坡头地区生物结皮覆盖区土壤种子库组成及垂直分布特征. 生态学报, 2017, 37(22)：7614-7623.

[31] 赵文智, 白四明. 科尔沈沙地围封草地种子库特征. 中国沙漠, 2001，21(2)：204-208.

[32] 刘晓霞. 浑善达克沙地土壤种子库结构与动态特征研究 [D ]. 呼和浩特: 内蒙古农业大学.

[33] 王刚, 梁学功. 沙坡头人工固沙区的种子库动态. 植物学报, 1995, 37(3) : 231-237.

[34] 赵丽娅, 李锋瑞, 张华, 王先之. 科尔沈沙地围封沙质草甸土壤种子库特征的研究. 生态学杂志, 2004, 23(2): 45-49.

[35］杜建会, 严平, 展秀丽, 俄有浩. 民勤绿洲白刺灌丛沙堆不同演化阶段表面抗蚀性及其影响因素. 应用生态学报, 2008, 19(4)：763-768.

[36] 曾彦军, 王彦荣, 南志标, 卫东, 陈善科, 李保尔. 阿拉善干旱荒漠区不同植被类型土壤种子库研究. 应用生态学报, 2003, 14(9)： 1457-1463.

[37］于洁, 高丽, 间志坚, 王育青. 库布齐沙漠东段不同演替阶段沙丘土壤种子库变化特征. 中国草地学报, 2015, 37(4): 80-85.

[38] Li N, Feng G, Tian C Y. Characteristics and dynamics of the soil seed bank at the north edge of Taklimakan desert. Science in China Series D: Earth Sciences, 2007, 50(S1) : 122-127.

[39] 王增如, 徐海量, 尹林克, 李吉玫, 张占江, 李媛. 塔里木河下游荒漠化过程土壤种子库特征. 中国沙漠, 2009, 29(5)：885-890.

[40] 李吉玫, 徐海量, 张占江, 叶茂, 王增如, 李媛. 塔里木河下游不同退化区地表植被和土壤种子库特征. 生态学报, 2008, 28(8)： 3626-3636.

[41］李新荣, 张志山, 王新平, 刘立超, 黄否. 干旱区土壤-植被系统恢复的生态水文学研究进展. 中国沙漠, 2009, 29(5): 845-852.

[42] 李宁, 冯固, 田长彦. 塔克拉玛干沙漠北缘土壤种子库特征及动态. 中国科学 D 辑 地球科学, 2006, 36(S2): 110-118.

[43] 张涛, 田长彦, 孙羽, 冯固. 古尔班通古特沙漠地区短命植物土壤种子库研究. 干旱区地理, 2006, 29(5): 675-681.

[44] Guo Q F, Rundel P W, Goodall D W. Horizontal and vertical distribution of desert seed banks : patterns, causes, and implications. Journal of Arid Environments, 1998, 38(3): 465-478.

[45] Guo Q F, Rundel P W, Goodall D W. Structure of desert seed banks: comparisons across four North American desert sites. Journal of Arid Environments, 1999, 42(1): 1-44. 